\title{
Species composition and role of exotic invasive pioneers in vegetation establishment on Mount Merapi Volcanic Deposits in Java, Indonesia
}

\author{
SUTOMO \\ Bali Botanic Gardens, Indonesian Institute of Sciences. Candikuning, Baturiti, Tabanan 82191, Bali, Indonesia. Tel./fax.: +62-368-21273/22051, \\ email: sutomo.uwa@gmail.com
}

Manuscript received: 30 October 2018. Revision accepted: 29 November 2018.

\begin{abstract}
Sutomo. 2018. Species composition and role of exotic invasive pioneers in vegetation establishment on Mount Merapi Volcanic Deposits in Java, Indonesia. Trop Drylands 2: 59-64. The volcanic deposits found in Mt. Merapi are relatively new in terms of years since the last known eruption. The objective of this study was to make use of the chronosequence method to describe changes in the species composition patterns in vegetation establishment, and to conduct observations on whether pioneer species, especially exotic and perhaps also invasive species, are decreasing or increasing species diversity in the succession. Results showed that the younger deposits were dominated by Athyrium macrocarpum, Polygonum chinense, Paspalum conjugatum and Cyperus flavidus. The older deposits were dominated by Anaphalis javanica, Imperata cylindrica, Polytrias amaura, and Eupatorium riparium. Invasive (native and exotic) pioneer species such as I. cylindrica, A. javanica, Calliandra callothyrsus, Polyosma ilicifolia, and E. riparium showed positive correlation with species diversity. It is important to understand the role of non-native, invasive alien species in the recovery process. Early recovery generally depends on these species to boost the succession, but in the longer term, invasive species may affect the successional trajectory.
\end{abstract}

Keywords: Invasive species, Merapi Volcano, vegetation, Indonesia

Abbreviations: NMDS: Non-metric Multi Dimensional Scaling; ANOSIM: analysis of similarity; PRIMER: Plymouth Routines In Multivariate Ecological Research.

\section{INTRODUCTION}

Purely mineral deposits, such as those from volcanic eruptions, preserve no "memories" of previous vegetation which is indicated by the absence of seed banks (Thornton 2007). Hence, in order to begin primary succession, colonization by pioneer species must occur from other undisturbed places. Vegetation establishment on volcanic deposits has been documented in many parts of the world, such as in the USA, Italy and Japan, and their rates have been shown to vary (Aplet et al. 1998; Dale et al. 2005b; Tsuyuzaki 1991). For example, plant establishment and spread on the debris-avalanche deposits were slow during the first years after eruption of Mt. St. Helens in USA (Dale et al. 2005b). In contrast, Taylor (1957) has reported that six years after Mt. Lamington in Papua New Guinea erupted, vegetation regeneration was very rapid and this included pioneer species such as Saccharum spontaneum, Imperata cylindrica, Pennisetum macrostachyum, species of Vitaceae and several ferns. Mt. Krakatau in Indonesia had at least 64 vascular plant species (dominated by grasses species such as $S$. spontaneum and I. cylindrica) which colonized the island 3 years after the eruption (Thornton 2007).

Although they may be useful for specific purposes, such as re-vegetation or fallowing barren land, pioneer species, especially exotic species, may also have an undesired invasive characteristic that could damage the ecosystem.
Eupatorium spp and Lantana camara have been shown to have the tendencies to become over-dominant and, thus, may inhibit species diversity (Kunwar 2003; Raghubanshi and Tripathi 2009). Eupatorium riparium and E. sordidum have been found to dominate the forests groundcover layer in Mt. Gede-Pangrango National Park in West Java, Indonesia at an elevation of 1,200-1,500 m (Wuragil 2009).

In the process of primary succession, there are two processes in which plant re-establishment through invasion could occur. Firstly, there has to be propagules from an outside source transported to the bare area. Secondly, germination of these propagules must occur, get to maturity stage and propagate, leading to the increase in the number of individual plants (Eggler 1959). Survival and recovery of plants following volcanic disturbance will be much affected by the type and intensity of volcanic activity, nutrients moved by the volcano, distance from the crater and types of propagules from near undisturbed areas (Dale et al. 2005a).

Mt. Merapi ( $7^{\circ} 35^{\prime} \mathrm{S}$ and $\left.110^{\circ} 24^{\prime} \mathrm{E}\right)$ is administratively located in two provinces, Central Java (Magelang, Boyolali and Klaten Districts) and Yogyakarta (Sleman District). In Yogyakarta Province, Mt. Merapi $( \pm 2,900 \mathrm{~m}$ asl $)$ is located approximately 30 kilometres north of Yogyakarta City. Mt. Merapi is a representative of landforms, soils and vegetation of volcanic mountains that typify a large portion of montane ecosystems in Java (Whitten et al. 1996). The volcanic deposits found in Mt Merapi are relatively new in 
terms of years since last known eruption with the last known eruptions occurring between 1994 and 2006 (MVO 2006). Although no detailed account is available of vegetation condition within the blast area after eruption, preliminary observations showed that it is rapidly developing. Therefore, the present study is significant in generating useful baseline data for the management of volcano-based-national park ecosystems in the region and elsewhere in Indonesia. The objective of this study was to make use of chronosequence method to describe the patterns of vegetation establishment on Mt. Merapi, and to conduct observations on whether pioneer species, especially exotic and perhaps also invasive ones, are decreasing or increasing species diversity in the succession.

\section{MATERIALS AND METHODS}

\section{Study site and period}

Vegetation was sampled in five nuées ardentes deposits in 2008 (Figure 1). Nuèes ardentes are hot turbulent gas and fragmented material resulting from a collapsed lava dome that rapidly moves down the volcanic slope (Dale et al. 2005). The accumulation of this material is called a nuées ardentes deposit and it may be up to ten meters thick
(Franklin et al. 1985). These deposits were different ages (time since last known eruption); the youngest deposit was 2 years old and the oldest was 14 years old.

\section{Data collection}

Sampling took place in ten 0.025 ha circular plots for each deposit age with plots assigned randomly to grid cells on map (Dale et al. 2005b). A total of 50 sample plots were obtained and each plot was located in the field with reference to compass and a handheld Global Positioning System GPS (Garmin E-Trex Legend). We measured plant abundance as density; a count of the numbers of individuals of a species within the plot. The abundance of seedlings, herbaceous and other pioneering shrubs were recorded. Their local name and species name, when possible, were noted. Vascular plant nomenclature was based on Backer and Bakhuizen van den Brink (1963). Within each quadrat, site physical characteristics (altitude, slope, distance to the crater and deposit thickness) were determined. Altitude, slope and distance to the summit were measured in the field. Altitude and distance to the summit was measured using a GPS and cross-checked with 1:25,000 topographic maps. A clinometer (Suunto clinometers) was used to determine the slope (in degrees).
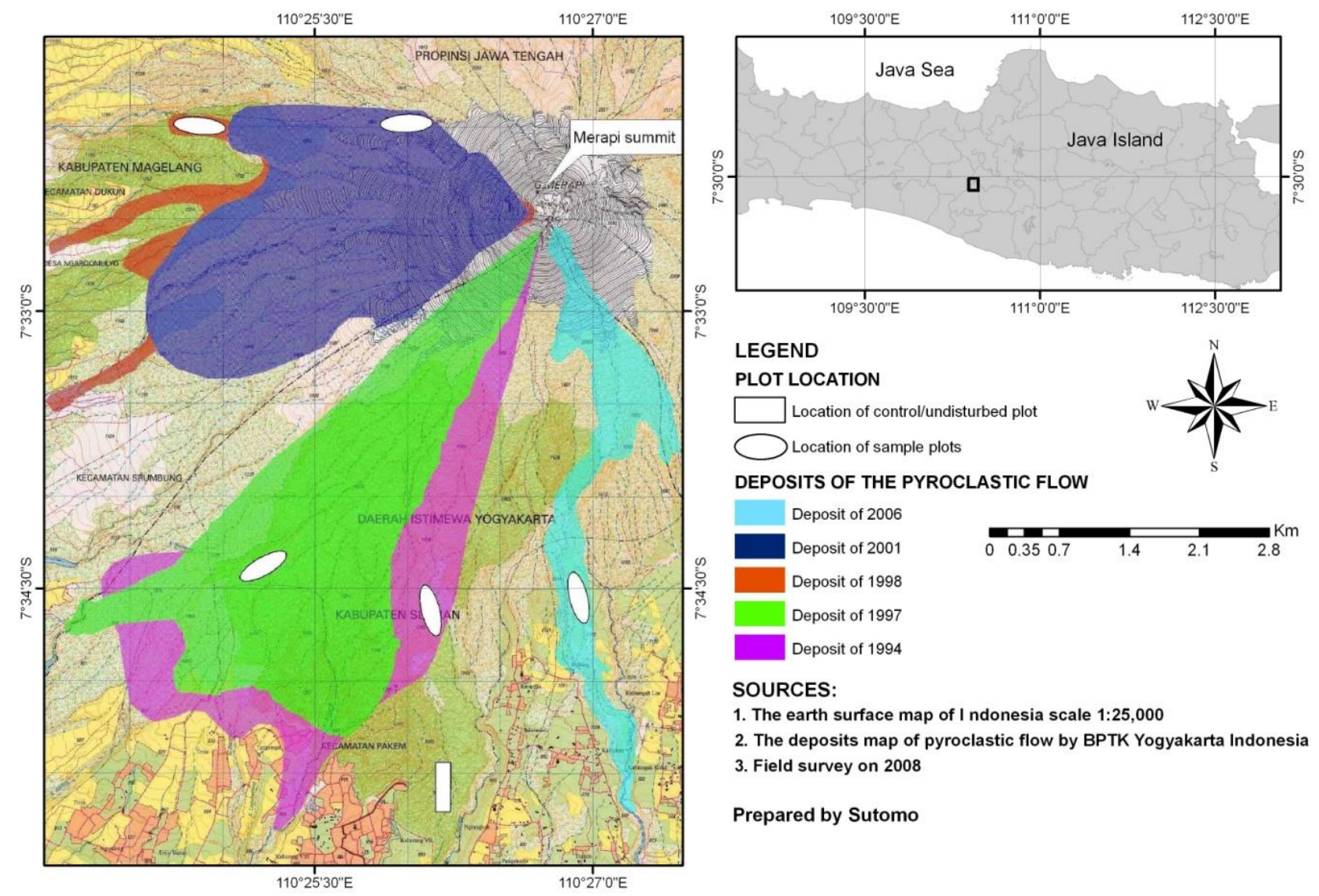

Prepared by Sutomo

Figure 1. Map of Mt. Merapi National Park's eruption deposits. Circular symbols refer to position of sampling sites at each deposit. Rectangle refers to position of an undisturbed forest 


\section{Data analysis}

Shannon-Wiener species diversity at each deposit (age category) was calculated using the DIVERSE feature for diversity measurement available in PRIMER V.6 (Clarke and Gorley, 2005). Differences between age categories (deposits) were tested for significance using one-way ANOVA and Tukey's Highly Significance Different (HSD) test. To examine the correlation between selected species and Shannon-Wiener species diversity, Spearman's bivariate correlation was computed to obtain the strength and nature of the relationship (Ramaharitra 2006). We tested differences in community composition between deposits using data on species abundance (density) per plot. The data were square-root transformed prior to constructing resemblance matrix based on Bray-Curtis similarity. Non-metric Multi Dimensional Scaling (NMDS) ordination diagram was then generated based on the resemblance matrix. Variation in community composition between deposits was subsequently tested for significance using one-way ANOSIM (analysis of similarity). The $\mathrm{R}_{\text {ANOSIM }}$ statistic values, generated by ANOSIM, are a relative measure of separation of the a priori defined groups. A zero (0) indicates that there is no difference among groups, while one (1) indicates that all samples within groups are more similar to one another than any samples from different groups. These analyses were done using PRIMER V.6 (Clarke 1993; Clarke and Gorley 2005).

\section{RESULTS AND DISCUSSION}

The number of species presents varied as time progressed with a rising trend of species richness and diversity over time (Table 1) and significant difference in species richness and diversity among deposits was detected (ANOVA $P=0.05$ ). There was a tendency of species richness to decrease with time at first, and then increase to become stable after more than 10 years. 2006 and 2001 were not statistically different, 1998, 1997 and 1994 were not different, but younger and older deposits were significantly different. Species diversity decreased slightly then returned to similar levels. The highest diversity was on the 1997 deposit whereas the lowest were in 2001 and 1998. Youngest and oldest deposits were not significantly different.

Table 1. Differences in species richness and diversity between groups of nuées ardentes deposit in Mt Merapi.

\begin{tabular}{lcc}
\hline Age group & $\begin{array}{c}\text { Mean species } \\
\text { richness }\end{array}$ & $\begin{array}{c}\text { Mean species } \\
\text { diversity }\end{array}$ \\
\hline Deposit 2006 & $4.1( \pm 1.59)^{\mathrm{a}}$ & $1.03( \pm 0.30)^{\mathrm{ab}}$ \\
Deposit 2001 & $2.9( \pm 0.56)^{\mathrm{a}}$ & $0.95( \pm 0.29)^{\mathrm{a}}$ \\
Deposit 1998 & $6.5( \pm 1.26)^{\mathrm{b}}$ & $0.95( \pm 0.34)^{\mathrm{a}}$ \\
Deposit 1997 & $6.6( \pm 1.26)^{\mathrm{b}}$ & $1.38( \pm 0.16)^{\mathrm{b}}$ \\
Deposit 1994 & $6.4( \pm 1.35)^{\mathrm{b}}$ & $1.3( \pm 0.35)^{\mathrm{ab}}$ \\
\hline
\end{tabular}

Figure 2 shows that Mt. Merapi was dominated by species such as Athyrium macrocarpum, Polygonum chinense, Paspalum conjugatum and Cyperus flavidus. These species were either present at very low to intermediate abundance or were not present in the older deposits. The older deposits were dominated by species such as A. javanica, I. cylindrica, Polytrias amaura and E. riparium. These species were either present at very low abundance or were not present in the younger deposits, which indicated that the dominance of these species is related to the development of the habitat over a period of several years at the sites. I. cylindrica, A. javanica and $A$. macrocarpum dominated the deposits colonization. A. macrocarpum dominated the colonization in the youngest (2006) deposit, where it then decreased sharply in 2001 deposit, but only to increase again in 1998 and 1997 deposits whereas in the oldest deposit (1994) $A$. macrocarpum decreased in abundance. I. cylindrica and $A$. javanica abundance was absent in the youngest deposit but then increased throughout the younger deposits and declined in the oldest deposit. Although they both finally declined in the oldest deposit, A. javanica still retains the highest abundance. Comparable phenomenon was also found in Mt. St. Helens primary succession, where cover of the early pioneer pearly everlasting (Anaphalis margaritacea) increased after the eruption but then declined in the older phase (Dale et al. 2005b). The decrease in I. cylindrica abundance may be due to the absence of fire which normally stimulates flowering (Collins and Jose 2009) and perhaps competition with other dominant species such as Polyosma ilicifolia and E. riparium in the older sites.

The mean abundance of the invasive alien species $I$. cylindrica showed a positive correlation $(\rho=0.514)$ with Shannon-Wiener diversity index (Table 2). Similar positive correlations were shown by the native species $A$. javanica $(\rho=0.416), \quad$ E. riparium $(\rho=0.582)$, Calliandra calothyrsus $(\rho=0.250)$ and the invasive $P$. ilicifolia $(\rho=$ 0.349). Positive correlation coefficient indicates that the increase in abundance of these species is correlated with the increase in species diversity. These correlations, however, were not relatively strong.

Table 2. Spearman's bivariate correlation analysis between selected species and Shannon-Wiener species diversity

\begin{tabular}{lc}
\hline Species & Correlation coefficient \\
\hline Imperata cylindrical $^{I}$ & $+0.514^{*}$ \\
Eupatorium riparium $^{l}$ & $+0.582^{*}$ \\
Anaphalis javanica & $+0.416^{*}$ \\
Calliandra calothyrsus $^{*}$ & $+0.250^{*}$ \\
Polyosma ilicifolia $^{I}$ & $+0.349^{*}$ \\
\hline Note: The correlation is significant at 0.01 levels. Plus $(+)$ sign $^{\text {indicates positive correlation and superscript }\left({ }^{1}\right) \text { indicates invasive }}$ \\
alien species
\end{tabular}




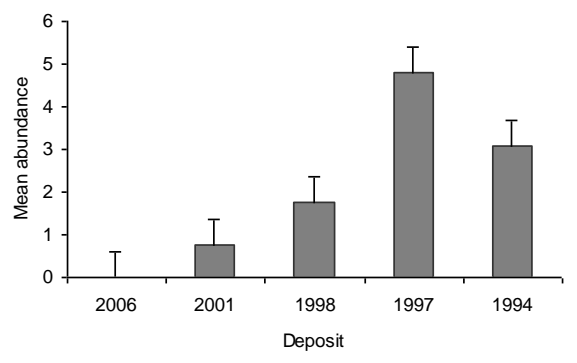

A

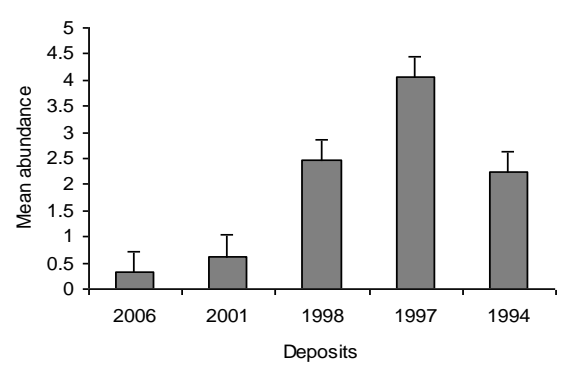

D

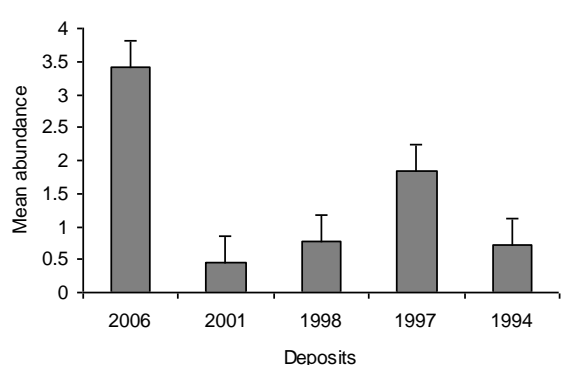

B

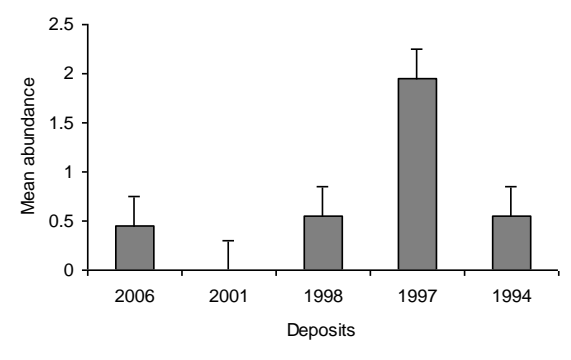

$\mathbf{E}$

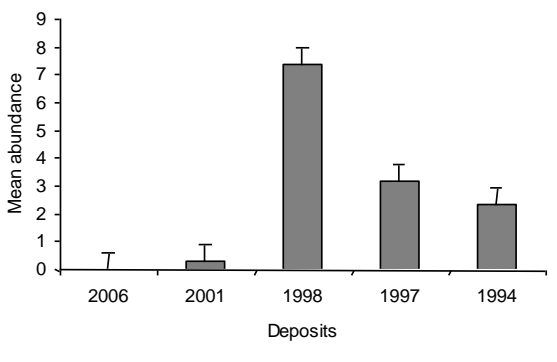

C

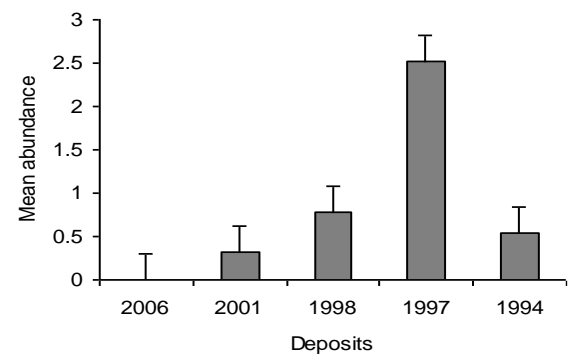

$\mathbf{F}$

Figure 2. Mean abundance (count of the numbers of individuals of a species within the plot) of selected species within fifty 0.025 ha circular plots in the 2006, 2001, 1998, 1997 and 1994 nuées ardentes deposits. A. Anaphalis javanica, B. Athyrium macrocarpum, C. Imperata cylindrica, D. Eupatorium riparium, D. Calliandra calothyrsus, E. Polyosma ilicifolia

It is important to understand the role of non-native, invasive alien species in the recovery process; many of the phenomena in early recovery depend on these species to boost the succession, but in the longer term invasive species may affect the successional trajectory (Dale and Adams 2003). In a severely disturbed habitat, facilitation has a more vital role in species change and restoration, whereas competition tends to be important in a more productive and established habitat (Callaway and Walker 1997; Walker et al. 2007). In the primary succession on Mt. Merapi, sites with high abundance of I. cylindrica had high species diversity (Table 2). I. cylindrica is an aggressive alien invader that has a long record of colonizing cleared lands in Indonesia (A. Hamblin, personal communication). Domination by Imperata of nuées ardentes deposits on Mt. Merapi is presumably due to its widely spreading rhizomes and its wind-dispersed seeds (Jonathan and Hariadi 1999). Imperata may have contributed indirectly to the increase in the number of species colonizing the deposits, especially in the early stages, by assisting in ameliorating the deposits (Walker and del Moral 2003).

As with Imperata, sites with high abundance of $A$. javanica also showed an increase in species diversity (Table 2). A. javanica (Figure 3) is a pioneering shrub endemic to Java and Bali often found in groups in an active crater valley or on new volcanic montane soil. It is able to thrive in such poor substrates owing to its mycorrhizas, which increase its intake of nutrients by enlarging the area covered by the roots (van Steenis 1972; Whitten et al. 1996). This native species may have directly facilitated establishment of the later species by providing shade and organic material (Dale et al. 2005b).

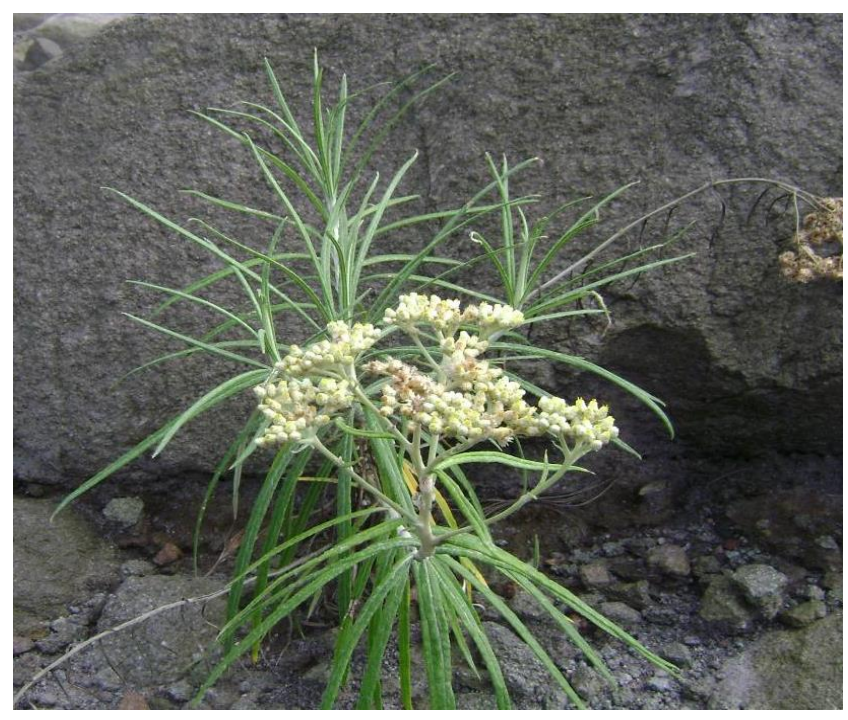

Figure 3. A. javanica, a native species that was able to establish early in the succession following Mt. Merapi eruption by lodging among rocks

Because nitrogen is generally the most limiting essential macro-nutrient in new soil materials (Lambers et al. 2007), nitrogen-fixing species are often regarded as the main facilitators in primary succession, because they can directly influence establishment by providing nitrogen (Walker et al. 2003). The nitrogen-fixing legume $C$. calothyrsus also showed positive correlation with species diversity (Table 2). Native of Mexico, this species has been widely introduced in many tropical regions. $C$. callothyrsus is able to grow on a wide range of soil types, including the 
moderately acidic soils of volcanic origin that are a common feature in Southeast Asia (Palmer et al. 1994).

Other invasive species also showed positive correlation with the diversity index and perhaps might have a role in facilitation. E. riparium abundance increased out through aged deposits in the primary succession sites except in the oldest deposit. This species was also the dominant groundcover species in Kaliurang, an intact forest on the southern slope of Mt. Merapi (Sutomo 2004). This alien species had significant $(\mathrm{P}=0.01)$ positive correlation with species diversity (Table 2) and may have indirectly facilitated the co-occurring species such as Gnaphalium japonicum and Melastoma affine by assisting in stabilizing and preventing erosion on the deposit site. However, over domination by this invasive species could be a problem itself. The Mistflower or Eupatorium is native to South America, and this unpalatable and highly competitive species has become a problem elsewhere such as in Nepal (Kunwar 2003).

These findings seem to contradict the view that, as invasive increase, the diversity would decline, as shown in the decrease of diversity in a site with abundant cover of Lantana in Vindhyan dry tropical forest in India (Raghubanshi and Tripathi 2009). However, the findings in Vindhyan may reflect the future condition of the succession sites in Mt. Merapi. In longer periods, domination of invasive alien species may limit the chance of recruitment of other native species, including seedlings of woody species, and hence reduce the diversity, and even change the successional trajectory and ecosystem function (Dale et al. 2005b; Hobbs and Huenneke 1992; Raghubanshi and Tripathi 2009; Standish et al. 2009).

Plant establishment in primary succession is also largely influenced by the development of the site's physical environment. Generally, nitrogen and phosphorus are the most limiting essential macronutrients in new volcanic soil materials (A. Hamblin, personal communication, 28 May 2009). In the course of physical weathering of the materials in the new substrates through time, phosphorus will become available for plants (Walker and Syers 1976). For nitrogen, nitrogen-fixing plants such as legumes make this nutrient available for later plant species in the succession (Bellingham et al. 2001; Walker et al. 2003). Furthermore, the role of organic matter is also prominent in the retention of water and nutrients to support the growth of the species occurring there (Hodkinson et al. 2002).

Although it is not possible to provide a definitive explanation for the process and mechanism of recovery and establishment in primary succession, the observations show that vegetation does become established in the volcanic deposits of Mt. Merapi. If the process and mechanism of recovery and establishment in the primary succession is to be examined, a long-term study of the vegetation dynamics is needed. Such studies are an essential complement to chronosequence studies; hence, the establishment of permanent sampling plots and/or re-sampling the chronosequence sites is recommended. However, the understanding gained from this study provides the prospect of adapting strategies for succession-based management and restoration strategies in these volcanic ecosystems.

\section{ACKNOWLEDGEMENTS}

Gratitude goes to Tri Prasetyo and Kuspriyadi Sulistyo from Merapi National Park management, Ministry of Forestry Republic of Indonesia and to Soewarno HB from Faculty of Forestry, Gadjah Mada University, Yogyakarta. Our gratitude also goes to Prof. Ann Hamblin for insightful discussion, Mbah Maridjan, the late caretaker of Mt. Merapi and to the excellent fieldwork team, i.e., Gunawan, Ali and Indri for field assistance.

\section{REFERENCES}

Aplet GH, Hughes RF, Vitousek PM. 1998. Ecosystem development on Hawaiian lava flows: biomass and species composition. J Veg Sci 9: 17-26.

Backer CA, Bakhuizen van den Brink RC. 1963. Flora of Java. The Rijksherbarium, Leiden.

Bellingham PJ, Walker LR, Wardle DA. 2001. Differential facilitation by a nitrogen-fixing shrub during primary succession influences relative performance of canopy tree species. J Col 89: 861-875.

Callaway RM, Walker LR. 1997. Competition and facilitation: A synthetic approach to interactions in plant communities. Ecology 78 : 1958-1965.

Clarke KR. 1993. Non-parametric multivariate analyses of changes in community structure. Aust J Ecol 18: 117-143.

Clarke KR, Gorley RN. 2005. PRIMER: Plymouth Routines in Multivariate Ecological Research. PRIMER-E Ltd., Plymouth.

Collins AR, Jose S. 2009. Imperata cylindrica, an exotic invasive grass, changes soil chemical properties of forest ecosystems in the Southeastern United States. In: Kohli RK, Jose S, Singh HP, Batish DR (eds). Invasive Plants and Forest Ecosystems CRC Press, London.

Dale VH. Adams WM. 2003. Plant re-establishment 15 years after the debris avalanche at Mount St.Helens, Washington. Sci Total Environ 313 (1-3): 101-113

Dale VH, Acevedo JD, MacMahon J. 2005a. Effects of Modern Volcanic Eruptions on Vegetation. In: Marti J, Ernst G (eds). Volcanoes and the Environment. Cambridge University Press, New York.

Dale VH, Campbell DR, Adams WM. Crisafulli CM, Dains VIP, Frenzen M, Holland RF. 2005b. Plant succession on the Mount St. Helens Debris-Avalanche deposit. In: Dale VH, Swanson FJ, Crisafulli CM (eds). Ecological Responses to the 1980 Eruption of Mount St. Helens. Springer, New York.

Eggler WA. 1959. Manner of invasion of volcanic deposits by plants, with further evidence from Parricutin and Jorullo. Ecol Monogr 29: 267284.

Franklin JF, MacMahon JA, Swanson FJ, Sedell JR. 1985. Ecosystem responses to catastrophic disturbances: Lesson from Mount St. Helens. Nat Geog Res 1: 198-216.

Heyne K. 1987. Tumbuhan Berguna Indonesia. Yayasan Sarana Wana Jaya, Jakarta.

Hobbs R J, Huenneke LF. 1992. Disturbance, diversity and invasion: Implication for conservation. Conserv Biol 6: 324-336.

Hodkinson ID, Webb NR, Coulson SJ. 2002. Primary community assembly on land-the missing stages: why are the heterotrophic organisms always there first? J Ecol 90: 569-577.

Jonathan J, Hariadi BPJ. 1999. Imperata cylindrica (L.) RaeuschelIn. In: de Padua LS, Bunyapraphatsara N, Lemmens RHMJ (eds). Plant Resources of South-East Asia No. 12 (1): Medicinal and Poisonous Plants 1. Backhuys Publisher, Leiden.

Kunwar RM. 2003. Invasive alien plants and Eupatorium: Biodiversity and livelihood. Himalayan J Sci 1: 129-133.

Lambers HJ, Raven A, Shaver GR, Smith SE. 2007. Plant nutrientacquisition strategies change with soil age. Trends Ecol Evol 23: 95103.

MVO. 2006. Prekursor Erupsi Gunung Merapi. Geological Department, Indonesian Ministry of Energy and Mineral Resources, Yogyakarta. [Indonesian]

Palmer B, Macqueen DJ, R. Gutteridge C. 1994. Calliandra calothyrsus-a multipurpose tree legume for humid locations. In: Gutteridge RC, 
Shelton MH (eds). Forage Tree Legumes in Tropical Agriculture. Tropical Grassland Society of Australia Inc., Queensland.

Raghubanshi AS, Tripathi, A. 2009. Effect of disturbance, habitat fragmentation and alien invasive plants on floral diversity in dry tropical forests of Vindhyan highland: a review. Trop Ecol 50: 57-69.

Ramaharitra T. 2006. The effects of anthropogenic disturbances on the structure and composition of rain forest vegetation. Trop Res Bull 25: 32-37.

Standish RJ, Cramer VA, Yates CJ. 2009. A revised state-and-transition model for the restoration of woodlands in Western Australia. In: Hobbs RJ, Suding K (eds). New Models for Ecosystem Dynamics and Restoration. Island Press, Washington.

Sutomo. 2004. Biomasa dan struktur komunitas tumbuhan bawah di hutan lindung Kaliurang Yogyakarta: Studi di petak 7 RPH Kaliurang. Universitas Gadjah Mada, Yogyakarta. [Indonesian]

Taylor BW. 1957. Plant succession on recent volcanoes in Papua. J Ecol 45: 233-243.

Thornton I. 2007. Island Colonization the Origin and Development of Island Communities. Ecological Reviews,.Cambridge University Press, Cambridge.
Tsuyuzaki S. 1991. Species turnover and diversity during early stages of vegetation recovery on the volcano Usu, Northern Japan. Veg Sci 2: 301-306.

van Steenis CGGJ. 1972. The Mountain Flora of Java. E.J Brill, Leiden.

Walker LR, Clarkson BD, Silvester WB, Clarkson BR. 2003.

Colonization dynamics and facilitative impacts of a nitrogen-fixing shrub in primary succession. Veg Sci 14: 277-290.

Walker LR, Walker J, del Moral R. 2007. Forging a New Alliance Between Succession and Restoration. In: Walker LR, Walker J, Hobbs RJ (eds). Linking Restoration and Ecological Succession. Springer, New York.

Walker RL, del Moral R. 2003. Primary succession and ecosystem rehabilitation. Cambridge University Press, Cambridge.

Walker TW, Syers JK. 1976. The fate of phosphorus during pedogenesis. Geoderma 15: 1-19.

Whitten T, Soeriaatmadja RE, Afiff SA. 1996. The ecology of Indonesia series volume II: The ecology of Java and Bali. Periplus, Hongkong.

Wuragil. 2009. Invasi Spesies Asing, Ancaman Satwa dan Flora Lokal Tempo Interaktif. https://tekno.tempo.co/read/178127/invasi-spesiesasing-ancaman-satwa-dan-flora-lokal. [Indonesian] 